\title{
The effects of various hormones and growth factors on the growth of human insulin-producing cell line in serum-free medium
}

\author{
Jae-Jeong Lee, ${ }^{1,2,5}$ Jai-Hyun Kwon, ${ }^{3}$ \\ Yong Keun Park, ${ }^{3}$ Ohoak Kwon ${ }^{4}$ and \\ Tai-Wook Yoon ${ }^{1}$ \\ 1 Biotechnology Laboratory, Boryung Central Research Institute, \\ Kunpo 435-050, Korea \\ 2 Department of Biology, College of Science, Korea University, \\ Seoul 136-791, Korea \\ 3 Graduate School of Biotechnology, Korea University, Seoul 136-791, \\ Korea \\ 4 Life Science Laboratory, Korea Basic Science Institute Seoul Branch, \\ Seoul 136-791, Korea \\ 5 Corresponding author
}

Accepted 3 November 1997

Abbreviations: FCS, fetal calf serum; DMEM, Dulbecco's modification Eagle's medium; F-12, Ham's F-12

\begin{abstract}
An insulin-producing cell line, $\mathrm{HB}$, was derived from immortalized human pancreatic $\beta$-cells transformed by SV40 DNA. To make serum free medium specific for the cells, it was necessary to select basal medium, hormones, growth factors and coating materials. First of all, human insulin-producing cell line was adapted serially to the culture medium containing minimum required (1\%) fetal calf serum (HB-1) from $10 \%$ fetal calf serum. The cells had a tendency to attach to the culture dishes coated with collagen or gelatin in the serum-free medium and showed a stronger attachment to collagen than to gelatin. For the basal medium selection, medium containing an equal mixture of RPMI 1640, Dulbecco's modified Eagle's medium, and Ham's F-12 (RDF) was shown to be the most suitable for the cells among 7 differently mixed basal media. The cells exhibited highly positive response to 7 factors including insulin-transferrin-selenium (ITS)complex in the basal medium. In addition, other 16 factors also influenced the cell growth positively. In contrast, 4 factors including aldosterone inhibited the cell growth. Cell growth was enhanced remarkably when the cells were cultured in the serum-free medium supplemented with all the seven positive factors, compared with in RDF serum-free medium.
\end{abstract}

ITS and linoleic acid-BSA were found to be essential for the cell growth. The growth was much higher in the medium containing 6 strong positive factors without either dexamethasone, glucagon, or thyrocal-citonin than in the medium containing all the 7 strong positive factors. It is suggested that the interaction between the individual positive factors must be considered in choosing the factors with which the serum-free medium is supplemented.

Keywords: insulin, cell growth, hormone, growth factor

\section{Introduction}

Cell growth, in general, is increased by various hormones and growth factors that are required nutritionally and environmentally for cell survival, proliferation, and protein synthesis (Morgan et al., 1950; Eagle, 1955; Bettger, 1986; Griffith, 1987). Most of them are present in serum which is added to the culture medium (Barns and Sato, 1980b; Murakami and Mausi, 1980; Clark and Chick, 1990). Growth factors are a group of polypeptides which control the proliferation and differentiation of normal cells. Normal growth factors are very similar in structure to oncogenic proteins, and some oncogene products act as growth factors (Stryer, 1988). The production of some oncogenic proteins are very high in transformed cells compared with that in normal cells, and the c-onc can be amplified more than thirty-fold in some human tumor cells, compared to that in normal cells. These cells in culture release into the culture medium growth factors that may confer the transformed phenotype on untransformed cells, and enable normal anchorage-dependent cells to proliferate in soft agar and possibly even in suspension conditions (Lazar, 1987). Unfortunately, it is obvious that hormone concentration varies widely from serum to serum (Waymouth, 1972), and, what is worse, serum addition increases the culture cost, purification problems and the possibility to introduce adventitious agents to the culture. The problems are significantly serious when cultures are scaled up for commercial production. In fact, attempts to purify the active component from cell cultured in serum-containing medium (Higuichi, 1973; Brooks, 1975) have provided a limited utility for most cell culturist. Therefore, it is desired to remove fetal calf serum (FCS) from media used for human pancreatic beta cells (HB) culture. In this aspect, serum-free medium is highly preferred to culture the cells for commercial product. Thus, serum-free culture has been widely used 
for production of biopharmaceutically active substances such as monoclonal antibodies, tissue plasminogen activators and lymphokines (Wolfe et al., 1988; Schneider, 1989), and for primary culture of tumor cell lines (Mather and Sato, 1979a; Bosch, 1981; Mcglowan, 1983).

Investigators in this field have recognized the problems associated with the complexity and defined nature of serum, and a number of different approaches have been taken to eliminate the requirement for a serum supplement in the culture medium. The first approach is the adaptation of the cell lines to the medium with no serum. In recent years, a few methods have been used to replace the serum in the culture medium with other factor. It is extremely difficult or impossible to make serum-free medium by eliminating unwanted hormones and growth factors from the serum medium. There is another approach which could solve the problem by developing serum-free media containing low concentrations of mitogenic and other proteins which will allow mammalian cell growth under defined condition. Several different serum free media designed for the growth of pancreatic islet cells have been previously reported (Fong et al., 1981; Clark and Chick, 1990). These formulas usually consist of a basal medium (Dulbecco's modifecation Eagle's medium [DMEM], Ham's [F-12], or a mixture of both) supplemented with insulin, transferrin, triiodothyronine, prolactin, growth hormone, and also an extract of protease peptone or the defined serum-free medium consisting of RPMI supplemented with human serum albumin, human transferrin, prolactin, insulin like growth factor-1, ethanolamine, phosphoethanolamine, and L-glutamine. The present work was undertaken to investigate hormones and other factors that stimulate growth of $\mathrm{HB}$ cells. First, the cells were made to adapt to low (1\%) serum medium, and the basal medium is selected. Optimal concentrations of hormones and growth factors were determined. Finally, the selected hormones and factors were mixed in the basal medium to make the serum-free media specific for HB cells.

\section{Materials and Methods}

\section{Cell cultures}

The insulin producing cells for stock batch were cultured in RPMI 1640 medium supplemented with $10 \%$ FCS (Sera Lab.), $22 \mathrm{mM}$ HEPES, $200 \mathrm{IU} / \mathrm{ml}$ penicillin, 200 $\mu \mathrm{g} / \mathrm{ml}$ streptomycin, $2 \mathrm{mM}$ glutamine, and $1 \mathrm{mM}$ sodium pyruvate (Gibco). The cells to be adapted to low serum medium were cultured in serum free medium (RDF) consisting of a 1:1:1 mixture of DMEM, F-12 and RPMI 1640 that included $22 \mathrm{mM}$ HEPES, $200 \mathrm{IU} / \mathrm{ml}$ penicillin, and $200 \mu \mathrm{g} / \mathrm{ml}$ streptomycin. Hormones and growth factors to be studied were added to RDF. Cells were incubated at $37^{\circ} \mathrm{C}$ under a humidified atmosphere of
$95 \%$ air $/ 5 \% \mathrm{CO}_{2}$.

\section{Adaptation to low serum medium}

Human insulin-producing cell line was serially adapted to the culture medium containing 1, 2, 5 and $7.5 \%$ FCS diluted from $10 \%$ FCS. The cells were detached from plates by incubation with $0.024 \%$ (w/v) trypsin/EDTA (Sigma) for $2-5 \mathrm{~min}$ at $37^{\circ} \mathrm{C}$, and trypsin/EDTA is then inhibited by adding $10 \%$ FCS culture medium. However, with the cells cultured in the medium containing below $5 \%$ FCS, soybean trypsin inhibitor (Sigma) instead of $10 \%$ FCS culture medium was used to neutralize the trypsin/EDTA after subculture and for cryopreservation. In general, the cells which were adapted to the low FCS culture media (less than 5\%) were cryopreserved in cell freezing medium (Sigma) and the others were cryopreserved in $90 \%$ serum and $10 \%$ dimethyl sulfoxide.

\section{Screening of basal medium}

Basal medium for HB cells is formulated with DMEM, F12 and RPMI (1 or $1: 1$, or $1: 1: 1$ mixture). The single or mixtures of basal media were RPMI (R), DMEM (D), F12 (F), DMEM/F-12 (D/F), RPMI/DMEM (R/D), RPMI/ F12 (R/F), RPMI/DMEM/F-12 (RDF) and Hybri-Max ${ }^{\circledR}$ (formulated serum-free and protein-free hybridoma medium) purchased from Sigma.

HB-1 and HB- 0.5 cells, serially adapted to the culture medium containing $1.0 \%$ and $0.5 \%$ FCS, were suspended at a density of approximately $5 \times 10^{4}$ cell/well in a 24well plate in $2 \mathrm{ml} \mathrm{RPMI}$ which contained $1 \%$ FCS (RPMI/ FCS [1\%]) and 0.5\% FCS (RPMI/FCS [0.5\%]). One day later, the cells were attached and spreaded. The cultures were washed twice with PBS, and each basal media at $3 \mathrm{ml} /$ well were added to 24 -well plates. On the fifth (HB1) and seventh day (HB-0.5) of incubation, the cell viability was assayed by trypan blue exclusion method.

\section{Screening of attachment factor}

Serum contains attachment factors such as fibronectin and serum-spreading factor which promote cell attachment to the substratum. In the absence of serum, The adaptation is induced by adding attachment factors such as fibronectin, collagen, or gelatin.

In the present experiment, attachment factor solution was made as follows: collagen was added to $0.1 \mathrm{M}$ acetic acid to obtain final $0.01 \%(\mathrm{w} / \mathrm{w})$ collagen solution and then stirred at room temperature for 1-3 $\mathrm{h}$ until dissolved. The collagen solution was then transferred to a glass bottle with a screw cap and chloroform was carefully layered on the bottom. The well plates were coated with 6-10 mg of collagen $/ \mathrm{cm}^{2}$, and the collagen was dried overnight at $24^{\circ} \mathrm{C}$ under the UV light in a sterile tissue culture hood. Gelatin solution $(2 \%, w / v)$ was prepared and sterilized by autoclaving at $121^{\circ} \mathrm{C}$ and 15 psi for 30 min. Wells were coated with $5-10 \mathrm{ml}$ of $2 \%$ gelatin 
solution $/ \mathrm{cm}^{2}$ and was dried at least for $2 \mathrm{~h}$ before the cells were seeded.

\section{Screening of hormone and growth factors}

Aqueous soluble agents were prepared as concentrated stock solutions with sterile distilled water or culture medium, and added directly to each cultured dish or plate. Tested agents included glucagon $(100 \mu \mathrm{g} / \mathrm{ml})$, insulin $(10 \mathrm{mg} / \mathrm{ml})$, ITS-complex (insulin, $5 \mu \mathrm{g}$; transferrin, $5 \mu \mathrm{g}$; selenium, 5 $\mathrm{ng} / \mathrm{ml})$, linoleic acid-BSA (10 $\mathrm{mg} / \mathrm{ml})$, leutenizing releasing hormone $(10 \mu \mathrm{g} / \mathrm{ml})$, neurotension $(20 \mu \mathrm{g} / \mathrm{ml})$, putrescine $(16.1 \mu \mathrm{g} / \mathrm{ml})$, somatostatin $(2 \mu \mathrm{g} / \mathrm{ml})$, sodium selenite $(20$ $\mu \mathrm{g} / \mathrm{ml})$, thrombin $(10 \mu \mathrm{g} / \mathrm{ml})$, thyrocalcitonin $(50 \mu \mathrm{g} / \mathrm{ml})$, thyrotropin releasing hormone $(20 \mu \mathrm{g} / \mathrm{ml})$, thyroxine $(20$ $\mu \mathrm{g} / \mathrm{ml})$, transferrin $(500 \mu \mathrm{g} / \mathrm{ml})$, platelet derived growth factor $(1 \mu \mathrm{g} / \mathrm{ml})$, epidermal growth factor $(10 \mu \mathrm{g} / \mathrm{ml})$, fibroblast growth factor $(2.5 \mu \mathrm{g} / \mathrm{ml})$, and nerve growth factor $(1 \mu \mathrm{g} / \mathrm{ml})$ purchased from Sigma.

Water-insoluble agents were dissolved in absolute ethanol. The agents included D-aldosterone $(100 \mu \mathrm{g} / \mathrm{ml})$, dexamethasone $(20 \mu \mathrm{g} / \mathrm{ml})$, dihydrotestosterone $(1 \mathrm{mg} / \mathrm{ml})$, $\beta$-estradiol $(20 \mu \mathrm{g} / \mathrm{ml})$, hydrocortisone $(50 \mu \mathrm{g} / \mathrm{ml})$, progesterone $(20 \mu \mathrm{g} / \mathrm{ml})$, prostaglandin $D_{2}(50 \mu \mathrm{g} / \mathrm{ml})$, E1 (50 $\mu \mathrm{g} / \mathrm{ml})$, E2 $(50 \mu \mathrm{g} / \mathrm{ml})$, F2 $(50 \mu \mathrm{g} / \mathrm{ml})$, and 3,3',5-triiodoL-thyronine $(20 \mu \mathrm{g} / \mathrm{ml})$ which was dissolved in $1 \mathrm{M} \mathrm{NaOH}$. All the reagents were purchased from Sigma.

HB cells $\left(5 \times 10^{4} /\right.$ well) were seeded in 12-well tissue culture plate, incubated with FCS (1\%) and allow to attach and spread. After overnight incubation, $1 \%$ serum culture medium was replaced with RDF plus the growth factors and hormones to be tested. Cells were cultured for 3 days, detached, and then cell number was counted by the trypan blue exclusion method.

\section{Optimal concentration of hormones and growth factors}

Optimal concentrations of ITS-complex, linoleic acid-BSA, glucagon, thyrocalcitonin, somatostatin, and thrombin for the cells were determined. Attached cells after 1 day culture in RPMI/FCS (1\%) were washed twice with RDF and incubated with RDF containing four different concentrations of the growth factors and hormones to be tested.

\section{Combination of hormones and growth factors}

In preliminary studies, we found that 7 hormones and growth factors alone increased cell growth rate, however, the medium containing all the factors at the defined concentration did not support the growth of the cells which could be explained by synergistic and/or antagonistic relationship among the factors. To find an appropriate combination of 6 available hormones and growth factors which support the growth of cells at similar rate as serum, the mixtures were made with each individuals, 2 factors, 3 factors, 4 factors an omission of either ITS-complex, linoleic acid-BSA, glucagon, thyrocalcitonin, somatostatin, thrombin from 6 agents. $5 \times 10^{5}$ cells/flask were seeded on $25 \mathrm{~cm}^{2}$ tissue culture flask (Falcon) and incubated with $4 \mathrm{ml} \mathrm{RPMI/FCS} \mathrm{(1 \% )} \mathrm{to} \mathrm{allow} \mathrm{cell} \mathrm{attachment.} \mathrm{These}$ cells were washed twice with $2 \mathrm{ml}$ RDF medium, and the medium was replaced with $4 \mathrm{ml}$ of RDF plus each combination of growth factors and hormones.

\section{Results}

\section{Adaptation to low serum concentration}

HB cells cultured in $10 \%$ FCS culture medium were serially adapted to the RPMI/FCS culture medium containing $1 \%$ FCS. Table 1 shows the HB cell growth cultured for 7 days in 10, 7.5, 5, 2.5 and $1 \%$ FCS culture medium. The cell numbers cultured in RPMI/FCS medium containing $1 \%$ FCS was only $7 \%$ of those in $10 \%$ FCS. HB cells grown in $10 \%$ FCS medium were serially adapted to $1 \%$ FCS culture medium, and the result shown in Table 2 indicate that cell growth in 1\% FCS culture medium was $50 \%$ of that grown in the culture medium containing $10 \%$ FCS.
Table 1. The number of cells cultured in media containing different concentrations of FCS. HB-cells in RPMI/FCS medium containing FCS 10\%, 7.5\%, 5\%, 2.5\%, 1\% were counted. Values are mean \pm S.E.M. of 6 experiments.

\begin{tabular}{ll}
\hline $\begin{array}{l}\text { FCS } \\
(\%)\end{array}$ & Cell No. $\left(\times 10^{5}\right)$ \\
\hline 10 & $2.48 \pm 0.15$ \\
7.5 & $1.82 \pm 0.16$ \\
5 & $1.20 \pm 0.05$ \\
2.5 & $0.42 \pm 0.04$ \\
1 & $0.18 \pm 0.01$ \\
\hline
\end{tabular}

Table 2. Numbers of cells serially adapted to the culture media containing different concentrations of FCS. HB-cells were cultured serially in RPMI/FCS medium (3 ml) containing FCS 10\%, 7.5\%, 5\%, 2.5\%, 1\%. Duplicate 25-cm² culture flasks (Falcon) were cultured for 5 day and were counted. Values are mean \pm S.E.M. of 6 experiments.

\begin{tabular}{lc}
$\begin{array}{c}\text { FCS } \\
(\%)\end{array}$ & Cell No. $\left(\times 10^{5}\right)$ \\
\hline 10 & $1.44 \pm 0.20$ \\
7.5 & $1.02 \pm 0.02$ \\
5 & $1.30 \pm 0.15$ \\
2.5 & $1.12 \pm 0.14$ \\
1 & $0.76 \pm 0.05$ \\
\hline
\end{tabular}




\section{Cell growth in basal media}

The effects of a single or mixtures with DMEM, F-12, RPMI, and Hybri-Max on cell growth were tested and the results are shown in Table 3. When the cells adapted to $0.5 \%$ and $1 \%$ of FCS were cultured in combination with D/F, RDF and H-Max, basal medium, they stimulated the cell growth. In the case of HB-1 and HB- 0.5 cell line, RPMI/ FCS (1\%) and RPMI/FCS (0.5\%) was relatively better than the other basal medium. The growth rate of the culture in $\mathrm{H}-\mathrm{Max}$ was very similar to that in RDF medium (cell numbers, $14.00 \pm 0.88$ and $13.22 \pm 0.19 \times 10^{4}$ cells in H-Max and RDF, respectively) among the nine media. RDF medium was found to be the best (Table 3 ).

\section{Effects of attachment factors on cell attachment}

Figure 1A shows $\mathrm{HB}$ cells after 3-day culture in serumfree RPMI medium on uncoated well plate. As expected, only a few cells are attached. Figure $1 \mathrm{~B}$ shows the same cells on 3-day culture on the plate in RPMI/FCS (1\%) which were confluent. The cells grown on the plate were
Table 3. Effects of various basal media on the cell growth. HB cells were made to adapt to $0.5 \%$ or $1 \% \mathrm{FCS}$. Equal numbers $\left(5 \times 10^{4}\right)$ of $\mathrm{HB}$ cells were cultured in the indicated basal medium for 7 days $(0.5 \%$ serum) or 5 days ( $1 \%$ serum) and the cell number was counted. Cell numbers in $\times 10^{4}$ are shown. H-MAX (Hybri-Max); DMEM:F-12 (1:1), R/D; RPMI:DMEM (1:1), R/F; RPMI: F-12 (1:1), and RDF; RPMI:DMEM: F-12 (1:1:1), and FCS (RPMI/FCS [1\%]), SF (RPMI/SF). Values are mean \pm S.E.M. of 6 experiments.

\begin{tabular}{lrr}
\hline \multirow{2}{*}{ Basal medium } & \multicolumn{2}{c}{ Serum (\%) } \\
\cline { 2 - 3 } & \multicolumn{1}{c}{0.5} & \multicolumn{1}{c}{1.0} \\
\hline H-Max & $3.88 \pm 0.22$ & $14.00 \pm 0.88$ \\
F-12 (F) & $2.23 \pm 0.51$ & $9.15 \pm 1.10$ \\
DMEM (D) & $2.38 \pm 0.33$ & $6.50 \pm 0.58$ \\
RPMI (R) & $1.13 \pm 0.31$ & $1.70 \pm 0.23$ \\
D/F & $5.05 \pm 0.30$ & $11.40 \pm 1.15$ \\
R/D & $2.60 \pm 0.15$ & $7.93 \pm 0.52$ \\
R/F & $2.92 \pm 0.54$ & $6.78 \pm 0.62$ \\
RDF & $6.13 \pm 0.32$ & $13.22 \pm 0.19$ \\
R/FCS & $11.17 \pm 0.92$ & $21.17 \pm 0.96$ \\
R/SF & $1.22 \pm 0.04$ & $4.75 \pm 0.20$ \\
\hline
\end{tabular}
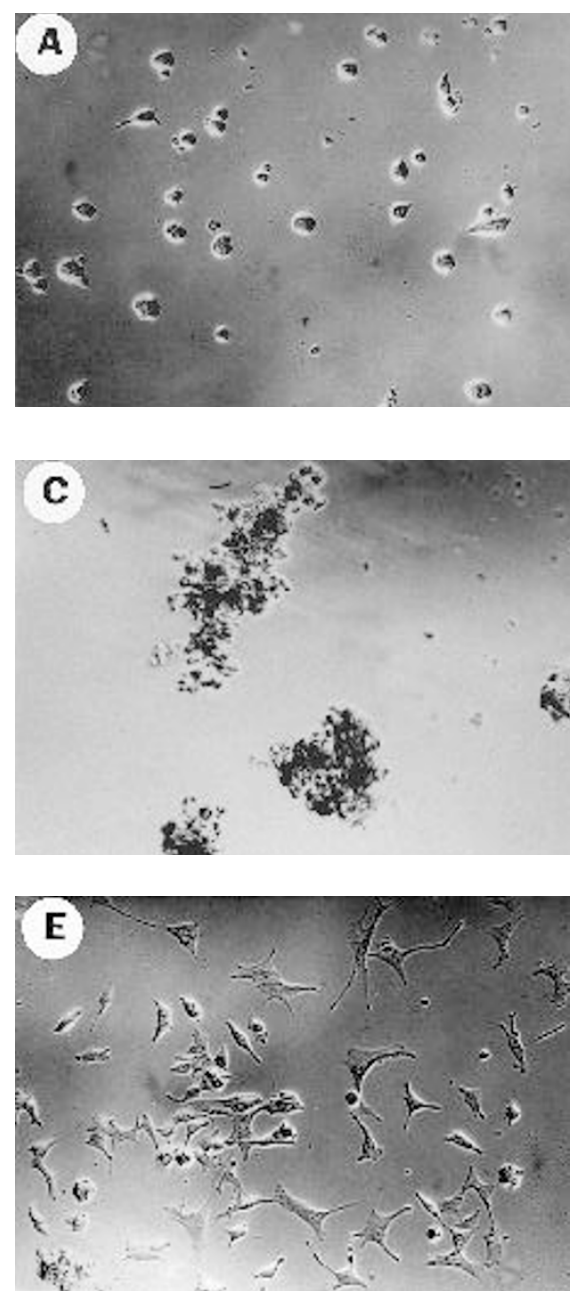
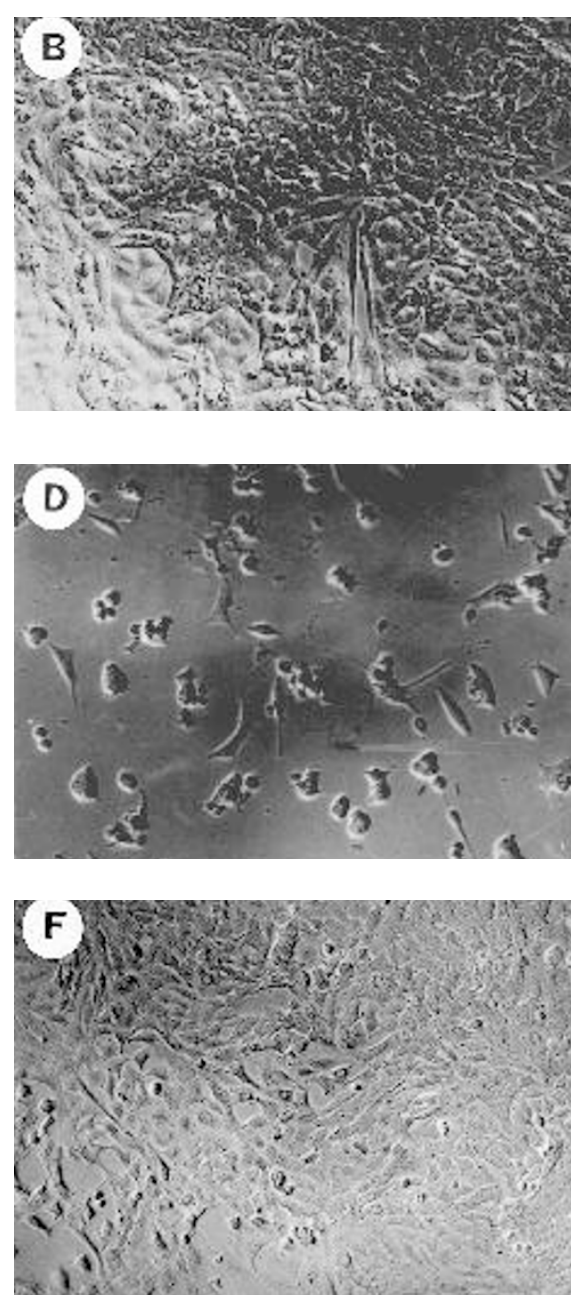

Figure 1. Phase-contrast micrographic morphology of insulin-producing HB cells in the wells coated with gelatin and collagen. (original magnitude $\times 100$ ). A, non-coating+RPMI/SF;

B, non-coating+RPMI/FCS (1\%); $C$, gelatin coating+ RPMI/SF; $D$, gelatin coating+RPMI/FCS (1\%); $\mathrm{E}$, collagen coating+RPMI/SF; $\mathrm{F}$, collagen coating+RPMI/FCS (1\%). 
coated with gelatin (Figure 1C and 1D). Figure 1C shows that the cells were aggregated and floating (Figure 1C). Figure 1D shows that a few cells are attached and spread out. When the plates were coated by collagen (Figure $1 \mathrm{E}$ and $\mathrm{F}$ ), a few cells are attached and proliferated in serum-free RPMI (Figure 1E). Figure 1F shows confluent growth in RPMI/FCS (1\%).

\section{Effects of hormones and growth factors}

Effect of hormones and growth factors on the HB cell growth are shown in Table 4. FCS was found to be the best among the factors tested to stimulate the HB cell growth. ITS-complex, linoleic acid-BSA, glucagon, thyrocalcitonin, somatostatin, and thrombin were also stimulatory. Aldostrone, thyronine, estradiol, sodium selenite showed rather inhibitory effects. Optimal

Table 4. Responsivenesses of insulin-producing cells to growth factors and hormones. HB cells were culture in 12-well tissue culture plates. The effects of various agents on the cell growth were tested as described in the 'Methods'. Values are mean \pm S.E.M. of 6 experiments.

\begin{tabular}{lc}
\hline \multicolumn{1}{c}{ Addition (per ml) } & Relative cell No. \\
\hline None & 1.00 \\
Fetal calf serum $(1 \%, \mathrm{v} / \mathrm{v})$ & $6.15 \pm 0.77$ \\
ITS Complex $(5 \mu \mathrm{g})$ & $2.98 \pm 0.09$ \\
Linoleic acid-BSA $(1 \mathrm{mg})$ & $2.98 \pm 0.02$ \\
Glucagon $(10 \mu \mathrm{g})$ & $2.34 \pm 0.82$ \\
Thyrocalcitonin $(50 \mathrm{ng})$ & $2.03 \pm 0.30$ \\
Somatostatin $(50 \mathrm{ng})$ & $1.88 \pm 0.07$ \\
Thrombin $(100 \mathrm{ng})$ & $1.87 \pm 0.07$ \\
Dexamethasone $(500 \mathrm{ng})$ & $1.79 \pm 0.40$ \\
Hydrocortisone $(5 \mu \mathrm{g})$ & $1.67 \pm 0.45$ \\
Transferrin $(\mathrm{Human})(100 \mu \mathrm{g})$ & $1.65 \pm 1.20$ \\
Epidermal growth factor $(10 \mathrm{ng})$ & $1.57 \pm 0.17$ \\
Insulin $(20 \mu \mathrm{g})$ & $1.53 \pm 0.61$ \\
Thyrotropin Hormone $(10 \mathrm{ng})$ & $1.46 \pm 0.36$ \\
Platelet-Derived growth factor $(10 \mathrm{ng})$ & $1.43 \pm 0.88$ \\
Prostaglandin F2 $(500 \mathrm{mg})$ & $1.38 \pm 0.44$ \\
Prostaglandin D2 $(500 \mathrm{ng})$ & $1.32 \pm 0.71$ \\
Nerve growth factor $(10 \mathrm{ng})$ & $1.31 \pm 0.12$ \\
Prostaglandin E1 $(500 \mathrm{ng})$ & $1.27 \pm 1.00$ \\
Fibroblast growth factor $(100 \mathrm{ng})$ & $1.22 \pm 0.40$ \\
Progesterone $(20 \mathrm{ng})$ & $1.22 \pm 0.13$ \\
Neurotensin $(200 \mathrm{ng})$ & $1.21 \pm 0.18$ \\
Prostaglandin E2 $(500 \mathrm{ng})$ & $1.10 \pm 0.10$ \\
Triiodothyronine $(250 \mathrm{ng})$ & $1.10 \pm 0.06$ \\
Putrescine $(16.1 \mu \mathrm{g})$ & $1.04 \pm 0.77$ \\
Leutenizing hormone $(40 \mathrm{ng})$ & $1.03 \pm 0.61$ \\
Aldosterone $(10 \mu \mathrm{g})$ & $0.93 \pm 0.30$ \\
Thyroxine $(50 \mathrm{ng})$ & $0.83 \pm 0.30$ \\
Estradiol $(10 \mathrm{ng})$ & $0.80 \pm 0.13$ \\
Sodium selenite $(2 \mu \mathrm{g})$ & $0.74 \pm 0.24$ \\
\hline
\end{tabular}

concentrations of the factors are shown in Table 5 . The optimal concentrations of ITS, somatostatin, linoleic acid-BSA, dexamethasone and thyrocalcitonin were 2.5 $\mu \mathrm{g} / \mathrm{ml}, 2.5 \mathrm{ng} / \mathrm{ml}, 0.5 \mathrm{mg} / \mathrm{ml}, 25 \mu \mathrm{g} / \mathrm{ml}$ and $250 \mathrm{ng} / \mathrm{ml}$ respectively. Glucagon and thrombin also increased the cell number as the concentrations increase, and their optimal concentrations were $20 \mu \mathrm{g} / \mathrm{ml}$ and $200 \mathrm{ng} / \mathrm{ml}$.

\section{Effects of various growth stimulants in combination or alone the cell growth}

Table 6 shows the results obtained when seven factors which has been shown to be stimulatory were employed either in combination of all the factors or in omission of a single factor from the total combination. The result demonstrated that $1 \%$ FCS has the most stimulatory effect on the cell growth, whereas RDF (basal medium) hardly supported growth. The combination of seven putatively stimulating factors (the third line) was somewhat less effective than the 1\% FCS. The omission of ITS complex ([1], insulin + transferrin + selenium) had the most drastic effect on the cell growth, cell growth being completely hampered. On the contrary, the omission of dexamethasone (7) restored the stimulatory effect to the

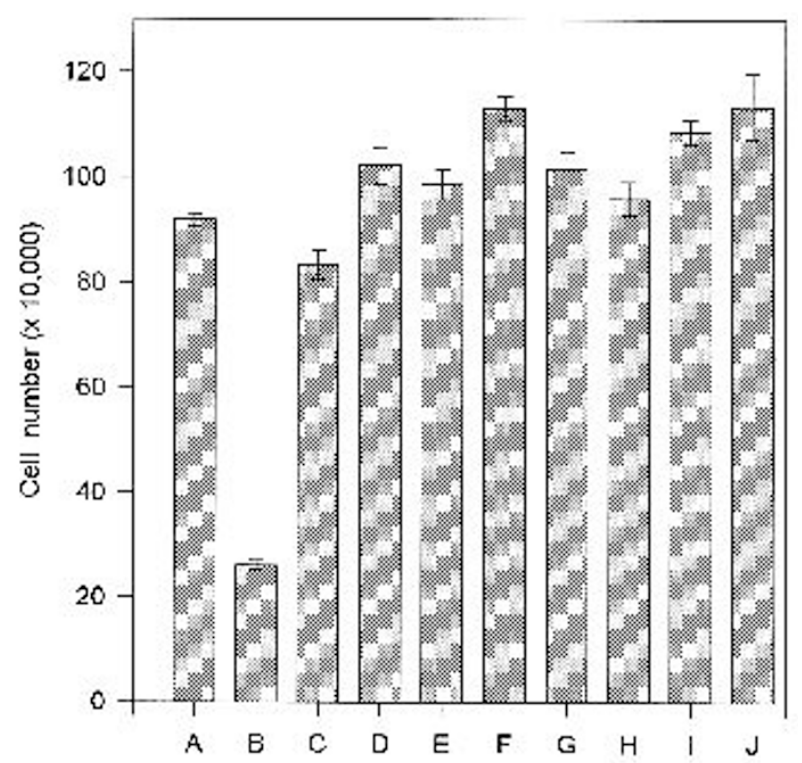

Figure 2. Cell growth responses to combined growth factors and hormones in RDF medium. A, FCS; B, RDF; C, ITS-complex; D, thyrocalcitonin + thrombin; E, linoleic acid-BSA + somatostatin; $F$, linoleic acid-BSA + somatostatin + thrombin; $G$, linoleic acid-BSA + glucagon + thrombin; $\mathrm{H}$, linoleic acid-BSA + glucagon + somatostatin + thrombin; I, linoleic acid-BSA + thyrocalcitonin + somatostatin + thrombin; J, linoleic acid-BSA + glucagon + thyrocalcitonin + somatostatin. ITS-complex was added to D, E, $F, G, H, I$. Values are mean \pm S.E.M. of 6 experiments. 
Table 5. The effects of 4 different concentrations of the factors on HB cell growth. Values are mean \pm S.E.M. of 6 experiments.

\begin{tabular}{|c|c|c|}
\hline Hormone and growth factor & Concentration (per ml) & Cell Number $\left(\times 10^{4}\right)$ \\
\hline \multirow[t]{4}{*}{ ITS } & $0.5 \mu \mathrm{g}$ & $2.54 \pm 0.30$ \\
\hline & $2.5 \mu \mathrm{g}$ & $3.73 \pm 0.75$ \\
\hline & $5 \mu \mathrm{g}$ & $3.11 \pm 0.42$ \\
\hline & $10 \mu g$ & $3.13 \pm 0.21$ \\
\hline \multirow[t]{4}{*}{ Linoleic acid-BSA } & $0.1 \mathrm{mg}$ & $2.84 \pm 0.82$ \\
\hline & $0.5 \mathrm{mg}$ & $3.29 \pm 0.44$ \\
\hline & $1 \mathrm{mg}$ & $3.03 \pm 0.13$ \\
\hline & $2 \mathrm{mg}$ & $3.13 \pm 0.23$ \\
\hline \multirow[t]{4}{*}{ Glucagon } & $1 \mu g$ & $2.23 \pm 0.25$ \\
\hline & $5 \mu \mathrm{g}$ & $2.52 \pm 0.16$ \\
\hline & $10 \mu \mathrm{g}$ & $2.51 \pm 0.34$ \\
\hline & $20 \mu \mathrm{g}$ & $3.03 \pm 0.24$ \\
\hline \multirow[t]{4}{*}{ Thyrocalcitonin } & $5 \mu \mathrm{g}$ & $2.86 \pm 0.31$ \\
\hline & $25 \mu \mathrm{g}$ & $4.48 \pm 0.46$ \\
\hline & $50 \mu g$ & $3.60 \pm 0.89$ \\
\hline & $100 \mu g$ & $3.44 \pm 0.29$ \\
\hline \multirow[t]{4}{*}{ Somatostatin } & $5 \mathrm{ng}$ & $3.10 \pm 0.09$ \\
\hline & $25 \mathrm{ng}$ & $3.08 \pm 0.25$ \\
\hline & $50 \mathrm{ng}$ & $3.08 \pm 0.36$ \\
\hline & $100 \mathrm{ng}$ & $2.61 \pm 0.12$ \\
\hline \multirow[t]{4}{*}{ Thrombin } & $10 \mathrm{ng}$ & $2.18 \pm 0.11$ \\
\hline & $50 \mathrm{ng}$ & $2.56 \pm 0.34$ \\
\hline & $100 \mathrm{ng}$ & $2.84 \pm 0.29$ \\
\hline & $200 \mathrm{ng}$ & $3.32 \pm 0.31$ \\
\hline \multirow[t]{4}{*}{ Dexamethasone } & $50 \mathrm{ng}$ & $2.42 \pm 0.19$ \\
\hline & $250 \mathrm{ng}$ & $2.56 \pm 0.13$ \\
\hline & $500 \mathrm{ng}$ & $2.52 \pm 0.18$ \\
\hline & $1 \mathrm{mg}$ & $2.37 \pm 0.34$ \\
\hline
\end{tabular}

level of "total addition" of $11.47 \pm 1.05$ (the third line). This result suggests that dexamethasone is quite harmful to the growth of the cells and that the lower value of "total addition" from the $1 \%$ FCS might be due to the presence of dexamethasone in the "total addition".

The effects of combined factors on the cell growth are shown in Figure 2. The cell growth in those obtained with RDF medium supplemented with $1 \%$ FCS was used as control. The growth was compared with those in ITScomplex (ITS)-thyrocalcitonin-thrombin (TTh), ITS-linoleic acid-BSA (linoleic acid)-somatostatin (LS), ITS-linoleic acid-somatostatin-thrombin (LSTh), ITS-linoleic acidglucagon-thrombin (LGTh), ITS-linoleic acid-glucagonsomatostatin-thrombin (LGSTh), ITS-linoleic acid-thyrocalcitonin-somatostatin-thrombin (LTSTh), ITS-linoleic acid-glucagon-thyrocalcitonin-somatostatin (LGTS) showed significantly positive effects on the cell growth. RDF and ITS showed poorly positive effects but other combined factors.

\section{Discussion}

Most cell cultures require an addition of serum to synthetic medium for their maintenance and growth, because the serum provides nearly all the required hormones and factors (Griffiths, 1987). In fact, low serum concentration deprived of hormones no longer supports cells growth, unless the medium is supplemented with the hormones which have been removed (Griffiths, 1987). Clear evidence for the validity of this hypothesis has not yet been obtained due to difficulty to grow cells in the absence of serum. 
Table 6. Effects of combination of 7 growth factors and hormones. HB cells $\left(1 \times 10^{5}\right)$ cells/flask were seeded in $25 \mathrm{~cm}^{2}$ culture flask in culture medium containing $1 \% \mathrm{FCS}$. Following overnight incubation, the $1 \%$ serum culture medium was replaced with RDF containing the factors. After 5 day-culture, cells were counted by haemocytometer. 1 , ITS-complex, $2.5 \mu \mathrm{g} / \mathrm{ml}$; 2, linoleic acid-BSA, $0.5 \mu \mathrm{g} / \mathrm{ml} ; 3$, glucagon, $20 \mu \mathrm{g} / \mathrm{ml} ; 4$, thyrocalcitonin, $25 \mu \mathrm{g} / \mathrm{ml} ; 5$, somatostatin, $5 \mathrm{ng} / \mathrm{ml} ; 6$, thrombin, $200 \mathrm{ng} / \mathrm{ml} ; 7$, dexamethasone, $250 \mathrm{ng} / \mathrm{ml}$. Values are mean \pm S.E.M. of 6 experiments.

\begin{tabular}{lc}
\hline Addition/Omission & Cell Number $\left(\times 10^{5}\right)$ \\
\hline $1 \%$ FCS & $15.40 \pm 0.72$ \\
RDF (Basal medium) & $0.25 \pm 023$ \\
Total addition & $11.47 \pm 1.05$ \\
Omission (1) & $0.01 \pm 0.01$ \\
Omission (2) & $10.68 \pm 0.44$ \\
Omission (3) & $11.90 \pm 0.36$ \\
Omission (4) & $11.02 \pm 0.64$ \\
Omission (5) & $12.35 \pm 1.53$ \\
Omission (6) & $12.40 \pm 0.90$ \\
Omission (7) & $18.02 \pm 2.53$ \\
\hline
\end{tabular}

However, some serum-free, hormone-supplemented medium provides an excellent system to grow the cells. Since the adaptation procedure to low-serum media had been accepted as essential (Griffiths, 1987), human insulin-producing cell line was adapted to the culture medium containing $1 \%$ FCS serially diluted from $10 \%$ FCS in the present paper.

The various commercially available culture media differed widely in their abilities to support HB cell line without serum. RPMI and DMEM media could not sustain this cell line at all without serum: RPMI has no lipid nutrients or DNA precursors, while DMEM contains amino acids in high concentration, and F-12 contains linoleic acid, putrescine, several inorganic salts, DNA precursors, and many vitamins (Morton, 1970). Better growth of some cell lines were obtained in a mixture of F-12 and DMEM (Fong et al., 1981; Kumamoto et al., 1989). We have found that RDF medium which contains a relatively large number of components is adequate for HB cells. This may be due to the higher concentration of some components in RDF, compared with those in $F / D, R / D, R / F, F-$ 12, DMEM, and RPMI. Thus, RDF has been selected as a basal medium for $\mathrm{HB}$ cells.

Collagen substrates enhance the growth as well as the differentiation of many cells in culture (Kleiman et al., 1981). Islets consisting of mainly pancreatic $\beta$-cells are covered with collagen. This means that pancreatic $\beta$-cells have higher affinity toward collagen than gelatin. Even though the cells attached themselves to the culture dishes coated with either collagen or gelatin in the serum free medium, however, showed a stronger attachment to collagen than to gelatin. Collagen was often used as a coating material for cultured cells (Murray et al., 1978). Hormones and growth factors are likely to play a major role in proliferation and differentiation of cells in vitro, and most serum-free synthetic medium is supplemented with a various essential hormones and growth factors (Bagnarelli and Clementi, 1987). In the present paper, the HB cells exhibited highly positive responsiveness to every one of the seven factors including ITS-complex, and other sixteen factors also influences the cell growth positively. In contrast, four factors including aldosterone (Wehling et al., 1987), thyroxine (Seelig et al., 1981), estradiol (Lu et al., 1971) and selenium (Stadman, 1974) inhibited the cell growth. The serum-free medium supplemented with all seven positive factors unexpectedly inhibited HB cell growth. This results presented here strongly suggest that each factors in the mixture interact with each other synergically or antagonistically. Therefore, this relationship must be taken into consideration before preparing serum-free medium. Due to this fact, the factors were removed one by one from the mixture of the positive seven factors in order to find out inhibitory factors. The removal of either ITS-complex or linoleic acid from the mixture inhibited the cell growth completely. This is in good agreement with the fact that most serum-free medium requires insulin, transferrin, selenium and steroid hormone (Guilbert and Iscove, 1976, Hayashi and Sato, 1976; Barns and Sato, 1979). Also, omission of dexamethasone, thrombin, somatostatin, glucagon, thyrocalcitonin and all five factors enhanced the cell growth very significantly in agreement with previous findings (Barnes and Sato, 1980a, b; Philippe and Missoten, 1990). The human insulin producing cells showed higher growth in RDF supplemented with a mixture of highly concentrated ITScomplex, linoleic acid-BSA, thyrocalcitonin, somatostatin, thrombin and glucagon than medium containing only RDF/FCS (1\%). The reason could be partially due to the fact that serum might contain growth factors and hormones which are either inhibitory or stimulatory for the cell growth. Thus, omission of these inhibitory factors may allow the cells to grow better in the defined serumfree medium than in low serum medium (Mather and Sato, 1979b).

In summary, the human insulin producing cells can grow better in the serum-free medium supplemented with four factors than the medium containing RDF/FCS $(1 \%)$. This finding suggests that the cells can grow better in the more sufficiently defined serum-free medium than in $10 \%$ serum medium. This defined serum-free culture medium should be explored further for more efficiency to maintain the secretory function and the continuous growth of $\mathrm{HB}$ cells.

\section{References}

Bagnarelli, P. and Clementi, M. (1987) Serum-free growth human hepatoma cells. a review: Advan. in Biochem. Engin. Biotech. 34: 87-94 
Barnes, D. and Sato, G. (1979) Growth of a human mammary tumor cell line in a serum-free medium. Nature 281: 388-389

Barnes, D. and Sato, G. (1980a) Methods for growth of cultured cells in serum-free medium. Anal. Biochem. 102: 255-270

Barnes, D. and Sato, G. (1980b) Serum-free cell culture: a unifying approach. Cell 22: 649-655.

Bettger, W. J. and Mckeehan, W. L. (1986) Mechanism of cellular nutrition. Physiol. Rev. 66: 1-35

Bosch, J. V. D., Masui, H. and Sato, G.(1981) Growth characteristics of primary tissue cultures from heterotransplanted human colorectal carcinomas in serum-free medium Cancer Res. 41: 611-618

Brooks, R. F. (1975) Structure and function of plasma proteins (Allison, A. C., ed.) pp. 1112, Plenum, New York

Clark, S. A. and Chick, W. L. (1990) Islet cell culture in defined serum-free medium Endocrinology 126: 1895-1903

Eagle, H. (1955) Nutrient needs of mammalian cells in tissue culture. Science 122: 501 504

Fong, H. K. W., Chick, W. L. and Sato, G. H. (1981) Hormones and factors that stimulate growth of a rat islet tumor cell line in serum-free medium. Diabetes 30: 10221028

Griffith, J. B. (1987) Serum and growth factors in cell culture media an introductory review. Dev. Biol. Standard 66: 155-160

Guilbert, L. J. and Iscove, N. N. (1976) Partial replacement of serum by selenite, transferrin, albumin and lecithin in haemopoietic cell cultures. Nature 263: 594-595

Hayashi, I. and Sato, G. H.(1976) Replacement of serum by hormones permits growth of cells in a defined medium. Nature 259: 132-134

Higuichi, K. (1973) Cultivation of animal cells in chemically definded media, A review. Advan. Appl. Microbiol. 16: 111-136

Kleinman, H. K., Klebe, R. J. and Martin, G. R.(1981) Role of collagenous matrices in the adhesion and growth of cells. J. Cell Biol. 88: 473-485

Kumamoto, S., Ono, J., Tanaka, Y. and Takaki, R.(1989) Serum-free culture of insulinsecreting clonal cells from a hamster insulinoma. Diabet. Res. Clinic. Prac. 6: 1-8

Lu, K. H., Koch, Y. and Meites, J. (1971) Direct inhibition by ergocornine of pituitary prolactin release. Endocrinology 89: 229-223

Mather, J. P. and Sato, G. H. (1979a) The use of hormone-supplemented serum-free media in primary cultures. Exp. Cell Res. 124: 215-221
Mather, J. P. and Sato, G. H. (1979b) The growth of mouse melanoma cells in hormonesupplemented, serum-free medium. Exp. Cell Res. 120: 191-200

Mcgowan, J. A. and Bucher, N. L. R. (1983) Pyruvate promotion of DNA synthesis in serum-free primary culture of adult rat hepatocytes. In Vitro 19: 159-166

Morgan, J. G., Morton, H. J. and Parker, R. C.(1950) Nutrition of animal cells in tissue culture. I. Initial studies on a synthetic medium. Proc. Soc. Exp. Med. 73: 1-8

Morton, H. C. (1970) A survey of commercially available tissue culture media. In Vitro 6 : $89-108$

Murakami, H. and Mausi, H. (1980) Hormonal control of human colon carcinoma cell growth in serum-free medium. Proc. Natl. Acad. Sci. USA77: 3464-3468

Murray, J. C., Stingl, G., Kleinman, H. K., Martin, G. R. and Katz, S. I.(1978) Epidermal cells adhere preferentially to type IV (basement membrane) collagen. J. Cell Biol. 80: 197-201

Philippe, J. and Missotten, M. (1990) Dexamethasone inhibits insulin biosynthesis by destabilizing insulin mRNA in hamster insulinoma cells. Endocrinology 127: 1640-16445

Schneider, Y. J. (1989) Optimisation of hybridoma cell growth and mono- clonal antibody secretion in a chemically defined, serum-and protein-free culture medium. J. Immunol. Methods 116: 65-77

Seelig, S., Liaw, C., Towle, H. C. and Oppenheimer, J. H. (1981) Thyroid hormone attenuates and augments hepatic gene expression at a pre-translational level. Proc. Natl. Acad. Sci. USA 78: 4733-4737

Stadman, T. C. (1974) Selenium biochemistry. Science 183: 915-922

Stryer, L. (1988) Biochemistry, W. H. Freeman \& Company, New York

Waymouth, C. (1972) Growth nutrition and metabolism of cells in culture (Rothblat, G. H. and Cristofalo, V. J., eds.), Vol. I, p. 11, Academic Press, New York

Wehling, M., Armanini, D., Strasser, T. and Weber, P. C. (1987) Effect of aldosterone on sodium and potassium concentrations in human mono-nuclear leukocytes. Am. J. Physiol. 252: 505-508

Wolfe, R. A., Braatz, Z. A., Miller, D. A. and Heifetz, A. H. (1988) A new serum-free medium for monoclonal antibody production. Biotechniques 6 : 62-67 